\title{
Genetic Diversity of SARS-CoV2 and Environmental Settings: Possible Association with Neurological Disorders
}

\author{
Sharifa Hasana ${ }^{1} \cdot$ Md. Farhad Hossain ${ }^{2,3} \cdot$ Maroua Jalouli $^{4} \cdot$ Md. Tanvir Kabir ${ }^{5} \cdot$ Md. Giash Uddin $^{6}$. \\ Mir Imam Ibne Wahed ${ }^{7}$ - Tapan Behl ${ }^{8}$ • May N. Bin-Jumah ${ }^{9}$ - Mohamed M. Abdel-Daim ${ }^{10,11}$ • Lotfi Aleya ${ }^{12}$. \\ Md. Sahab Uddin ${ }^{1,3}$ (D)
}

Received: 19 August 2020 / Accepted: 25 November 2020 / Published online: 6 January 2021

(C) The Author(s), under exclusive licence to Springer Science+Business Media, LLC part of Springer Nature 2021

\begin{abstract}
The new coronavirus (CoV), called novel coronavirus disease 2019 (COVID-19), belongs to the Coronaviridae family which was originated from the sea market in Wuhan city in China, at the end of the year 2019. COVID-19 and severe acute respiratory syndrome (SARS) are belonging to the same family (Coronaviridae). The current outbreak of COVID-19 creates public concern and threats all over the world and now it spreads out to more than 250 countries and territories. The researchers and scientists from all over the world are trying to find out the therapeutic strategies to abate the morbidity and mortality rate of the COVID19 pandemic. The replication, spreading, and severity of SARS-CoV2 depend on environmental settings. Noteworthy, meteorological parameters are considered as crucial factors that affect respiratory infectious disorders, although the controversial effect of the meteorological parameter is exposed against COVID-19. Besides, COVID-19 accelerates the pathogenesis of the neurological disorders. However, the pathogenic mechanisms between COVID-19 and neurological disorders are still unclear. Hence, this review is focused on the genomics and ecology of SARS-CoV2 and elucidated the effects of climatic factors on the progression of COVID-19. This review also critically finds out the vulnerability between COVID-19 and neurological disorders based on the latest research data.
\end{abstract}

Keywords SARS-CoV2 $\cdot$ COVID-19 $\cdot$ Genetic diversity $\cdot$ Climatic factors $\cdot$ Neurological disorders

\section{Abbreviations}

$\mathrm{CoV} \quad$ coronavirus

COVID-19 novel coronavirus disease 2019

SARS severe acute respiratory syndrome

ACE-2 angiotensin-converting enzyme-2

Md. Sahab Uddin

msu-neuropharma@hotmail.com; msu_neuropharma@hotmail.com

1 Department of Pharmacy, Southeast University, Dhaka, Bangladesh

2 Department of Physical Therapy, Graduate School of Inje University, Gimhae, Korea

3 Pharmakon Neuroscience Research Network, Dhaka, Bangladesh

4 College of Science, King Saud University, P.O. Box 2455, Riyadh 11451, Saudi Arabia

5 Department of Pharmacy, Brac University, Dhaka, Bangladesh

6 Department of Pharmacy, Faculty of Biological Sciences, University of Chittagong, Chittagong, Bangladesh

\section{Introduction}

Indeed, novel coronavirus disease 2019 (COVID-19) is a pandemic that is threatening human health worldwide. Experiences gathered from strategies employed against severe acute respiratory syndrome-coronavirus (SARS-CoV) (identified in 2003) and recent developments in throughput molecular biology can be utilized to fight against the current epidemic

7 Department of Pharmacy, Faculty of Science, University of Rajshahi, Rajshahi, Bangladesh

8 Chitkara College of Pharmacy, Chitkara University, Punjab, India

9 Department of Biology, College of Science, Princess Nourah bint Abdulrahman University, Riyadh 11474, Saudi Arabia

10 Department of Zoology, College of Science, King Saud University, P.O. Box 2455, Riyadh 11451, Saudi Arabia

11 Pharmacology Department, Faculty of Veterinary Medicine, Suez Canal University, Ismailia 41522, Egypt

12 Chrono-Environnement Laboratory, UMR CNRS 6249, Bourgogne Franche-Comté University, Besançon, France 
of SARS-CoV2 $[1,2]$. Understanding the ecology, mode of transmission, and genetics of SARS-CoV2 may provide more control and preventive measures against the transmission of SARS-CoV2. A single individual with confirmed COVID-19 can infect about 3 healthy individuals [3, 4]. After the contamination, hands become a probable source of mechanical vector, and therefore are potential sites to prevent and terminate it from invading the body. Nonetheless, if SARS-CoV2 is not diminished at this stage, it can move towards its predilection site (i.e., cells of the lungs) where this virus utilizes its spikes to bind with angiotensin-converting enzyme-2 (ACE-2) receptors to gain access into cells in the respiratory epithelium. At this phase, innate lung immunity gets compromised by SARS-CoV2 [1].

Several studies have revealed that seasonal cycle is ubiquitously present in acute infectious diseases such as influenza, which is typically also found in respiratory viral infections [5, 6]. In this regard, for example, outbreaks of influenza take place in temperate regions every winter [6]. Besides, a study in the regions of Taiyuan, Beijing, Guangzhou, and Hong Kong showed that SARS outbreaks were significantly linked with temperature variations [7]. Growing evidence indicates that environmental conditions might influence the current outbreak of COVID-19 [8]. In a study, Chin et al. [9] reported that SARS-CoV2 exhibited higher stability at $4{ }^{\circ} \mathrm{C}$ but it showed sensitivity towards heat. Furthermore, as the incubation temperature elevated to $70^{\circ} \mathrm{C}$, survival time of SARS-CoV2 was reduced to $5 \mathrm{~min}$. Epidemiological studies have found a correlation between meteorological parameters and COVID-19; however, the results are controversial [10-12]. A study performed by Xie and Zhu [10] showed that when the mean temperature was below $3{ }^{\circ} \mathrm{C}$, an increase of $1{ }^{\circ} \mathrm{C}$ was linked with a $4.861 \%$ rise in the daily confirmed COVID-19 cases. In another study, Ma et al. [12] showed a positive link between daily COVID-19-related deaths and diurnal temperature range, and a negative link was observed with relative humidity. Nevertheless, Yao et al. [11] showed in a study that SARS-CoV2 transmission was not linked with temperature in cities of China. Indeed, COVID-19 is spreading globally at a rapid rate. Furthermore, there is a possibility that there will be a second wave of coronavirus $(\mathrm{CoV})$ infections [13, 14]. Therefore, it is important to identify the role of meteorological parameters in spreading COVID-19 to forecast the scenario of the upcoming months.

On the other hand, recent findings revealed a strong association of neurodegenerative disorders including dementia, Parkinson's disease (PD), and multiple sclerosis (MS) with $\mathrm{CoV}$ [15]. It has been confirmed in animal and human models that SARS-CoV2 can infect various brain regions including the brainstem [16], since it can enter directly via the olfactory nerves (i.e., without affecting the lung at the primary stage) [17]. A probable clarification of this phenomenon is that the infection develops as the glycoprotein spike of the virus binds with ACE2 receptors. Indeed, these receptors are extensively found in various regions of the brain including dopamine neurons of striatum and cardiorespiratory centers in the medulla $[18,19]$. However, the exact mechanism between SARSCoV2 and neurological disorders remains unclear. Therefore, this review finds out the vulnerability to SARSCoV2 infection as well as the critical interaction of COVID19 and neurological disorders.

\section{COVID-19 Epidemiology}

From December 30 through October 18, over 40 million COVID-19 cases and 1.1 million deaths have been reported globally [20, 21]. Since the last October 18, over 2.4 million new cases and 36,000 deaths of COVID-19 have been reported across all six WHO regions (Table 1). By WHO region, the European region has reported a rapid increase in cases $(927,433)$ and deaths (8386) in this past week with a $25 \%$ weekly increase in cases and $29 \%$ deaths compared to the previous week and contributing $38 \%$ of all new cases and $23 \%$ of all total deaths reported worldwide. Although the incidence of new infections is reported to be high in the region of the Americas and the South-East Asia region accounting for over half of new cases and deaths observed globally, the number of deaths continues to declines in these two regions. A gradual increase in the numbers of new cases and deaths were also observed in the Eastern Mediterranean, African, and Western Pacific regions. The countries reporting the highest number of new cases in the past seven days include India, the USA, France, Brazil, and the UK and remain the same as observed in seven days [20, 21].

\section{Molecular Mechanism and Genetic Diversity of SARS-CoV2}

In Wuhan, the SARS-CoV2's genomic sequences were isolated from an individual with COVID-19-related pneumonia and the size of the genome was found to be 29.9 kilobases $(\mathrm{kb})$ [22]. SARS-CoV2 contains positive-sense, single-strand RNA [1, 23]. The first genome of Wuhan SARS-CoV2 showed $82 \%$ nucleotide homology with human SARS-CoV and $89 \%$ with that of at SARS-CoV. Owing to the level of similarity with other SARS-CoVs, the current outbreak caused by the new virus was officially declared as SARS-CoV2 by the World Health Organization (WHO) and CoV study group of the International Committee on Taxonomy of Viruses on January 30, 2020 [24]. Interestingly, open-reading frames (ORFs) of SARS-CoV2 to some extent differ across members of the Coronaviridae family [25]. Within the first ORF, nearly $67 \%$ of SARS-CoV2 RNA are mainly located and translates the ppla and pplab polyproteins. Indeed, they encode 16 non- 


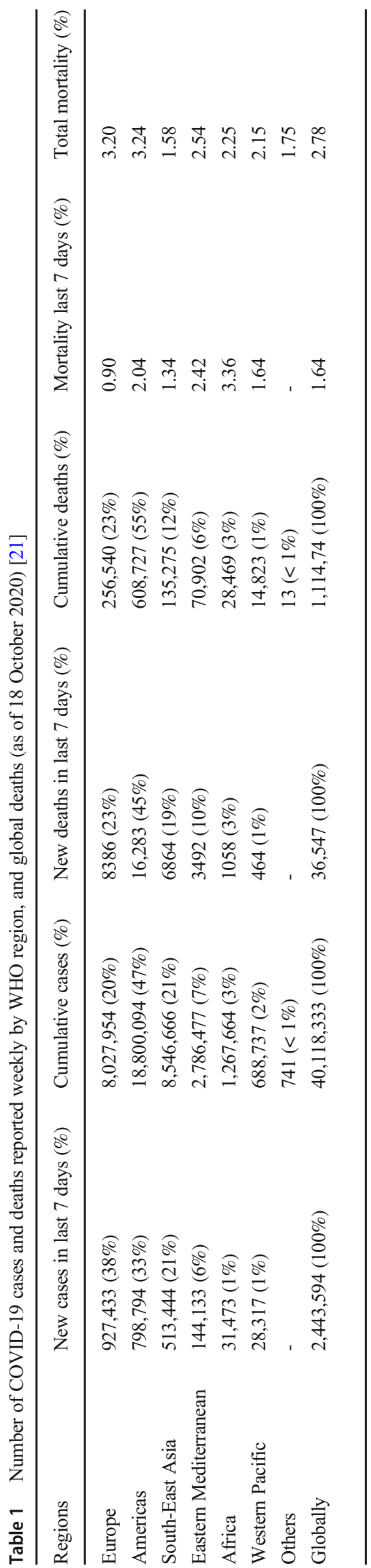

structural proteins (NSP). Rests of the ORFs are involved with coding accessory and structural proteins. On the other hand, the remaining portion of the genome encodes spike (S) glycoprotein, small envelope $(\mathrm{E})$ protein, matrix $(\mathrm{M})$ protein, and nucleocapsid $(\mathrm{N})$ protein [26]. The $\mathrm{N}$ and $\mathrm{E}$ proteins and specific accessory proteins are involved with arresting the initial innate immune response during the replication of SARS-CoV2. In a study, Angeletti et al. [27] observed mutation in NSP2 and NSP3 of SARS-CoV2, which significantly contributes to the differentiation and virulence of SARS-CoV2. Furthermore, Zhang et al. [28] reported that various forms of mutations in SARS-CoV2 were observed in Chinese COVID-19 patients.

Moreover, the virulence of $\mathrm{CoV}$ is linked with the effects of their structural and non-structural proteins. Out of all the structural proteins of $\mathrm{CoV}$, the $\mathrm{S}$ glycoprotein plays a major role in the COVID-19 pathogenesis [28]. S1 and S2 are the two subunits of S glycoprotein. S glycoprotein's homotrimer structure is composed of spikes on the surface of SARS-CoV2, which mediates the attachment with the receptors in host cells. In addition, on SARS-CoV2's S2 subunit, there is the presence of transmembrane domain, fusion peptide, and cytoplasmic domain which is highly conserved and might be regarded as a novel target for antiviral drugs [29]. At the genomic level, SARS-CoV2 and SARS-CoV contain 6 regions including $\mathrm{RD} 1, \mathrm{RD} 2, \mathrm{RD} 3, \mathrm{RD} 4, \mathrm{RD}$, and RD6. Among these regions, $\mathrm{RD} 1$ to RD3 are partial coding sequences of the ORF lab genes, while RD4 and RD5 are coded for the partial sequence of S gene. On the other hand, RD6 forms part of the ORF7b and ORF8 genes coding sequence. Since, there is a high homology ( $\geq 95 \%$ ) between proteins of SARS-CoV and SARS$\mathrm{CoV} 2$; thus, it is assumed that there is a structural similarity between these two viruses which might offer an insight into designing a candidate vaccine $[1,30,31]$.

Furthermore, the virulence mechanism and pathogenicity of SARS-CoV2 is associated with the non-structural and structural proteins via blocking host innate immune response and by mediating viral assembly and release, successively [29, 32]. In CoV genome, NSP3 is the largest protein and it possesses several domain activities essential for $\mathrm{CoV}$ replication [31]. It has also recently been indicated that COVID-19 pathogenesis is mainly induced by a mutation in NSP2 and NSP3. Other than the $\mathrm{E}$ protein, there were 42 mutations in all the major structural and non-structural proteins of SARS-CoV2. Furthermore, mutations were also identified in $\mathrm{N}$ protein, $\mathrm{M}$ protein, $\mathrm{S}$ glycoprotein, and ORF1ab polyprotein [33]. These findings raised a further question regarding whether or not mutations play a role in rapid global spread, alterations in antigenicity, and host tropism [33]. Recently, it has been demonstrated that SARS-CoV2 has mutated in different individuals, which is broadly divided into 6 genotypes [28]. Therefore, researchers need to critically analyze the SARSCoV2 genome to identify its precise mechanism of pathogenicity and probable future mutant strains. 


\section{Ligand and Receptor of SARS-CoV}

ACE-2 is found on the surface of the plasma membrane of the cells of lungs, intestine, arteries, heart, and also in renal tissues [34]. Besides the functions of ACE-2 in blood pressure regulation, SARS-CoV2 and other CoVs utilize this receptor protein to gain access into the host cells whereby it exerts harmful effects [34]. The outer surface of the virus is hydrophilic, while there is a lipophilic side on the inside, thus this virus can be destroyed through detergents [35]. It has been known that $\mathrm{S} 1$ and $\mathrm{S} 2$ are the 2 functional variants or subunits of $\mathrm{S}$ protein, where $\mathrm{S} 1$ variant is responsible for binding with the host cell receptor and the $\mathrm{S} 2$ variant is responsible for the viral fusion with the cell membranes of host cells (Fig. 1). In several $\mathrm{CoVs}, \mathrm{S}$ glycoprotein is cleaved at the border between the $\mathrm{S} 1$ and $\mathrm{S} 2$ subunits that are bound by a non-covalent bond in the pre-fusion state [35]. It has been found that the distal S1 subunit includes the receptor-binding domains and plays roles in stabilizing the fusion conformation of the membraneanchored S2 subunit [35]. Indeed, the aforesaid cleavage is supposed to induce the protein responsible for membrane fusion via widespread irreversible conformational alterations. Therefore, the entry of $\mathrm{CoV}$ in susceptible cells is a complex mechanism that involves a specific receptor-binding activity and proteolytic processing of the $\mathrm{S}$ protein to mediate viral fusion with the cell membranes [35]. It has been found that different $\mathrm{CoV}$ s use different domains within the $\mathrm{S} 1$ subunit to detect various attachments and entry receptors. Studies revealed that common human CoVs HKU1 and OC43 attach through the S domain A (SA) to 5-N-acetyl-9-O-acetylsialosides found on glycolipids and glycoproteins at the human cell surface to mediate entry into susceptible cells.

Indeed, SARS-CoV2 and SARS-CoV directly interact with the ACE-2 via subsequent binding of domain $\mathrm{B}(\mathrm{SB})$ to enter into host cells [36]. Since $\mathrm{S}$ glycoprotein of $\mathrm{CoV}$ is surfaceexposed and facilitates viral entry into host cells, thus it is the main target of neutralizing antibodies following infection and the focus of developing vaccines and therapeutic agents. It has been observed that $\mathrm{S}$ trimmers are widely decorated with $\mathrm{N}$ linked glycans that are important for appropriate folding and to gain access into host proteases and neutralizing immunological markers [37]. Indeed, remarkable similarities in structures and sequences observed in between $\mathrm{S}$ glycoproteins of both SARS-CoV2 and SARS-CoV indicate a relationship shared by these 2 species and identify the involvement with ACE-2 receptor by which humans are attacked. Furthermore, S glycoprotein perfectly fits within the ACE-2 receptor, which further suggests that battling against the current COVID-19 outbreak is largely reliant on the better understanding of the mechanisms of S glycoprotein and ACE-2 receptor on the
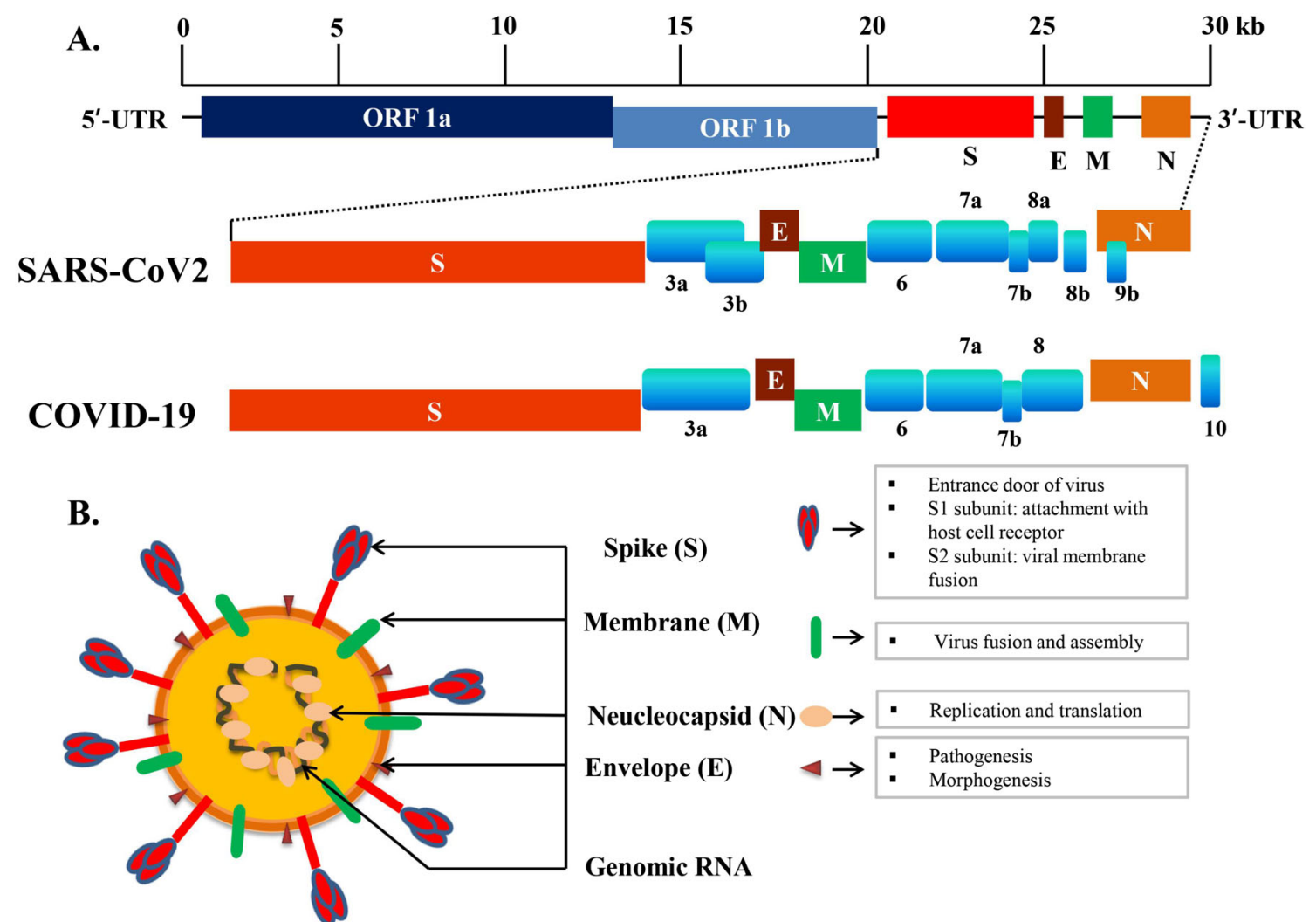

Fig. 1 Schematic diagram of SARS-COV2 and COVID-19 genome arrangement. A. The comparison between genomic and open-reading frames (ORFs) is mentioned. The full length of the genome sequence is $\sim 30 \mathrm{~kb}$. B. Viral RNA is associated with nucleocapsid (N) protein. Spikes (S), envelope (E) as well as membrane (M) are embedded in a lipid bilayer 
cells present in the lower respiratory tract. SARS-CoV2 is supposed to enter the host cell via cellular mediated endocytosis [37]. Therefore, strategies to fight against COVID-19 outbreak relies largely on a better understanding of the mechanisms of involvement of S glycoprotein on CoVs and ACE-2 receptor of host alveolar cells.

\section{Bionomics of SARS-CoV2}

As a human-susceptible virus, six CoVs have been recognized previously. Among them, four are regarded as low pathogenic CoVs and they cause mild respiratory tract illnesses that are similar to those of rhinoviruses [22]. While the other two, Middle East respiratory syndrome (MERS-CoV) and SARS$\mathrm{CoV}$ are highly pathogenic and potentially fatal to human beings. COVID-19 causing SARS-CoV2 has been identified as the seventh member of the CoVs family. It is suspected that bat is the reservoir host of the virus, based on the evolutionary analysis and findings from viral genome sequencing. Besides, SARS-CoV2 may also be transmitted from bats via an unknown intermediate host to humans. So far, snakes, pangolins, and bamboo rats have been suggested as probable intermediate hosts for SARS-CoV2. Possibly, these animals may have contacted the virus via urine, feces, and saliva of bats [38]. It has been observed that evolving viruses are increasingly using animals as a host via the zoonotic chain of transmission [38]. Therefore, it is imperative to recognize the potential animal sources of SARS-CoV2 transmission to take control of the pandemic.

\section{Transmission of SARS-CoV2}

A comprehensive study from China identified that human-tohuman transmission is the main way of obtaining SARSCoV2 outbreak [39]. A COVID-19 infected patient is the leading source of SARS-CoV2 infection [22]. Recent work reported that the respiratory droplets are associated with the contact of SARS-CoV2 transmission. It also stated that transmission occurs through airborne droplets and with close contact with each other $[38,40]$. It is important to mention that asymptomatic COVID-19 patient is also in the transmission process. Asymptomatic individuals can transmit the pathogen within 14 days of infection [41]. Another research indicated that SARS-CoV2 could be transmitted focally and/or orally [42]. Foodborne associated SARS-CoV2 from tainted food is yet to be elucidated. Transmission of SARS-CoV2 from mother to child was also assumed but many more studies are required to validate SARS-CoV2 vertical acquisition [43]. Another recent study also reported aerosol as the potential transmission modes of SARS-CoV2. This can remain contagious within 5-8 $\mathrm{h}$ in aerosol and for 5-7 days on fomite surfaces. Based on this evidence, WHO reported that aerosol transmission is possible [3].

\section{Air Transmission}

Recent evidence indicated that the asymptomatic COVID-19 patients are potential sources of transmission of the viral infection which can be spread through sneezing, coughing, talking to people at close distance, and that of unhealthy airflow [44]. However, it is thought that air contamination is not only the main mode of transmission of SARS-CoV2 [45] but also medical procedures like non-invasive positive pressure ventilation, high flow oxygen therapy, bronchoscopy, endotracheal intubation, bag and mask ventilation, suctioning and nebulization, induction of sputum, and cardiopulmonary resuscitation are the major sources of SARS-CoV2 aerosol production and release in air. The role of environmental pollution in several hospitals has been evaluated following the MERS$\mathrm{CoV}$ outbreak in Korea in 2015 as well as the survival and stability of MERS-CoV on air and surfaces were extensively studied [46].

\section{Water and Wastewater Transmission}

During the COVID-19 pandemic, maintenance of proper hygiene, ensuring safe drinking water, and sewage system play a pivotal role in protecting human health worldwide [47]. Although risks of SARS-CoV2 infection seemed to be less through the stool of an infected person, there is evidence that it may cause intestinal infection and can appear in stool sample [48]. Furthermore, studies demonstrated that about $2-10 \%$ of confirmed SARS-CoV2 cases are associated with diarrhea [49-51] and residual viral RNA of SARS-CoV2 were detected in the stool of COVID-19 patients [42, 52]. Yet, only one study has found the exposure of SARS-CoV2 from a cultured stool sample [53]. Recently, the presence of the SARS-CoV2 virus has been confirmed in wastewater sources and also indicated that the virus can survive in the sewage for days or weeks [54]. This finding could be a sensitive tool for tracking and monitoring the lifecycle of CoVs within communities [55, 56]. However, the survival of $\mathrm{CoV}$ in water resources depends upon some environmental factors including temperature, sunlight, and also the presence of organic compounds where the virus can easily adsorb and protect themselves against adverse conditions such as pathogenic microorganisms. There is no evidence of human type $\mathrm{CoV}$ transmission through contaminated drinking water [57] as reported by WHO. Generally, coated viruses are less environmentally favorable and are more sensitive to oxidizing agents for instance the SARS$\mathrm{CoV} 2$ is likely to be more rapidly inactivated in contact with chlorine than human intestinal viruses [53].

\section{Food, Food Packages, and Food Handler Transmission}

SARS-CoV2 transmission through food, food packages, and food handlers has not been identified as the contributing factor 
for the COVID-19 disease. However, based on the available evidence, the virus exists on the surfaces between a few hours to days; and thus, washing and sanitization is the best way to control the infection as suggested by center for disease control and prevention (CDC) [58]. Disinfection is strictly recommended during collection, relocation, and preparation of food including washing hands regularly, separating raw meat from other foods, cooking at high temperatures, and storing food in the refrigerator $[59,60]$. Persons involved in cooking in preparing and distributing food highly recommended for maintaining complete personal hygiene such as the use of apron, masks, gloves, and caps. Furthermore, it is also advised to cover the nose and mouth by bending elbow during sneezing or coughing, isolating COVID-19 symptomatic employees or personal contact with these patients, and maintaining a minimum distance of $6 \mathrm{ft}$ between persons. Set up of multiple points for hand washing and disinfection at work and washing and disinfection of surfaces with high contact by diluted sodium hypochlorite (0.1\%) are also recommended [59].

\section{Laboratory Investigations and SARS-CoV2}

For proper diagnosis of COVID-19 cases, extremely sensitive and precise laboratory protocols are required. It is important for the confirmed case, animal reservoir studies, contact tracing, and controlling the infection. It is not feasible to use the viral culture to develop an acute diagnosis, because it typically takes three days for SARS-CoV2 to induce apparent cytopathic effects in specified cell lines like VeroE6 cells. Usually, the SARS-CoV2 diagnosis is made in a laboratory of biosafety level-3 category that is unavailable in most of the health care facilities. Regulatory authorities do not approve a serum antibody-antigen rapid detection test as it can produce negative results. Because of such shortcomings, reverse transcription-polymerase chain reaction (RT-PCR) becomes the most successful COVID-19 screening tool globally [61]. Early in the pandemic, accessibility of complete SARS-CoV2 genome allowed the production of right primers and standard laboratory procedures for the detection of SARS-CoV2. RTPCR assays are designed to target any of the RdRp, envelope (E) as well as nucleocapsid $(\mathrm{N})$ genes of SARS-CoV2 [61]. Contaminants, inadequate sampling increases the chance of a false positive, and negative result. Usage of RdRp-based RT-PCR assays has started in several laboratories around the world [61].

Generally, SARS-CoV2 can be detected within 1-2 days in the upper respiratory tract samples before the onset of symptoms [62]. In moderate cases, the virus can continue to exist for 7-12 days, and in severe cases even for up to 14 days [62]. Viral RNA is also found in the stool of about $30 \%$ of COVID19 infected patients from the 5-day of onset and in moderate cases up to 4-5 weeks. Tests of the importance of fecal viral shedding for transmitting must also be carried out [34]. In Singapore, increased viral shedding of nasopharyngeal aspirates was observed up to 24 days after symptoms appear [63]. In Germany, long-standing viral shedding with high sputum viral load was observed with a gradually recovered patient [64]. For a long time, viral RNA may exist in body fluid which does not mean that the person is still infected [65]. It is required to use viral culture for virus isolation to demonstrate the virulence of the virus. According to Hoehl et al. [65] two asymptomatic cases are found with the infectious virus. It is suggested to confirm the SARS-CoV2 negative two consecutive tests should be done following a time interval of $>24 \mathrm{~h}$ with upper respiratory tract samples [66]. Sample collection in symptomatic should be done after the onset of 7 days or more than 3 days without fever. But after the initial positive test, it takes 14 days to observe with the asymptomatic patient, before taking the test to record the virus discharge. The serology tests to report SARS-CoV2 specific IgG antibody will be useful if properly validated and standardized [66]. The use of RTPCR should be designed to target two separate genes on separate events is important to discharge the patient as negative. It is necessary to discharge the patient as negative that the use of RT-PCR should be designed to target two different genes (e.g., E-gene and RdRP) on separate events.

\section{Climatic Factors and SARS-CoV2 Transmission}

The emergence and spread of infectious diseases are dependent on various environmental conditions. Scientists have found several factors involved in this occurrence. There is information for some virus transmission associated with climatic factors, while for others there has been no extrapolation. A controlled laboratory experiment on the influenza virus showed that absolute humidity favors its transmission [67]. This result was ultimately correlated with flu epidemiologic trends, and this mechanism is believed to extend to other respiratory viruses. There is a lack of detailed studies that have explicated the importance of humidity in the transmission of CoVs. Studies found that tropical and subtropical regions are the most favorable region for virus transmission [68]. It is fair to conclude that dry cold air in temperate regions impedes the transmission of flu. The importance of this factor for CoVs, however, is not decided yet. People usually stay at home in the winter season and this comes with less ventilation than in the summer.

Schools are marked places of significant transmission of infectious diseases. It is observed that respiratory viral infection transmission is increased during school days [69]. Therefore, school days affect in controlling infection such as chickenpox, measles, and flu. School is the place where a large number of students meet together in a limited area, and there is an increased probability of high humidity. The 
incidence of some respiratory viruses was interestingly variable in different age groups [69]. Till now, only a few children were classified as COVID-19 positive which may suggest children are less vulnerable to infection (European Centre for Disease Prevention and Control). However, COVID-19 positive children are contagious too. Asymptomatic children thus potentiate the risk of being infected. It can be concluded that the closure of the school will help to decrease SARSCoV2 transmission. It is assumed immunologically that the immune system of healthy people in summer is better than in winter [70]. A study also reported how melatonin influences immune responses. It is mainly seasonal and more immune response observed during the summer [71]. Another study also reported that vitamin D boosts the immune system [72]. This vitamin regulation requires sunlight which is mostly available in summer. It is a firm belief that supplementation of vitamin D can help to reduce the occurrence of respiratory viral infection [73]. It is an important research area of COVID19 recovery. Irrespective of seasonal variation, viral epidemics are predicted to increase exponentially, level off, and decrease over time. However, climate change and seasonality may significantly affect SARS-CoV2 transmission.

\section{COVID-19 Survival and Prospective Factors}

CoVs usually spread through gastrointestinal and respiratory tracts. These viruses normally cause common cold in vulnerable peoples and recover spontaneously without having serious effects while MERS, SARS can cause chronic pneumonia and gastritis [74]. The outflow and transmission of the virus from the body occurs within six days of infection and reaches its peak 4 days later $[75,76]$. The environmental factors needed for COVID-19 to survive and transmit are very evident; however, unlike animal $\mathrm{CoVs}$, there is very little information about the natural factors of transmission of COVID-19 [77]. Only a few previous studies found the relationship between temperature and humidity with the transmission of COVID-19.

\section{Temperature and Humidity}

The effect of temperature on human health can be different depending on the country to country or even region. It has been revealed that transmission of SARS-CoV2 and influenza virus is significantly affected by temperature. Besides, the novel COVID-19 and influenza virus can be transmitted depending on temperature which is also applicable for SARSCoV2 transmission. SARS-CoV2 can be spread out rapidly at a lower temperature because the immunity power of the host is likely to become weakened and unable to exert their proper functions in cold weather. As a result, the vulnerability of infection is raised quickly in the host. On the contrary, the viability of SARS-CoV2 is lower at higher temperatures (38 $\left.{ }^{\circ} \mathrm{C}\right)$. A study was performed with a $\mathrm{CoV}$ sample under various conditions of relative humidity and temperature. This study found that a half-life of 27 and $67 \mathrm{~h}$ at $30 \%$ and $50 \%$ humidity respectively was observed in these different conditions. Again, the half-life of $3 \mathrm{~h}$ was observed at $80 \%$ humidity. At $80 \%$ humidity with a temperature decrease of 6 degrees, there was an increase of half-life of $3 \mathrm{~h}$. This scenario was also reported with other seasonal flu [75]. Therefore decrease in temperature with increased humidity has an enormous impact on the half-life of the virus.

Several clinical trial reports suggested that transmission of droplets can be avoided using suitable masks but it is very tough to protect its dissemination in aerosols form [78, 79]. A study informed that the SARS virus spreading with aerosols and defective sewage systems caused the loss of many peoples in 2003 in Hong Kong [80]. In the same year, one SARS incident infected 22/122 travelers on a 3-h flight [81]. Strangely, people outside the 2 -m radius were involved in the exposure of a virus that was not transmitted by droplets and aerosols [82]. Although, it is hard to ascertain that the virus transmitted through only droplets and aerosols, but low relative humidity of the aircraft probably contributed to increasing the survival of the SARS virus. Later another study reported that the risk of the spread of $\mathrm{CoV}$ is insignificant aboard aircraft [83]. A Canadian study informed that open oxygen masks facilitate the transmission of the CoV. As viruses can spread from the masks through air droplets [84], it can be assumed that air exhaled through open oxygen mask can transmit the virus and pose a threat to health services. Future research is required to assess how SARS and related viruses survive and transmit in oxygenated air in a hot and humid environment. A study performed in hospital reported that the virus can transmit through aerosols. It also reported that proper ventilation systems can mitigate the disease spread [85]. It is believed that COVID-19 does not sustain at temperatures greater than $26{ }^{\circ} \mathrm{C}$ but can stay on the skin for about 5-10 min, on plastic materials for 6$12 \mathrm{~h}$ and metal for 12 hours (Fig. 2).

\section{Skin and COVID-19}

Researchers use human CoV 229E (HCoV-229E) instead of a human specimen for the COVID-19 test. Recently, a study reported that about $45 \%$ of the hand-infected virus exists and remains live after $1 \mathrm{~h}$ [86]. The survival time of this virus is longer than para-influenza virus type 3 which is vanished just after $10 \mathrm{~min}$. Another study was performed using human fingers washing with water and alcoholic hand sanitizer to determine viral response. It is found that using water the concentration of $\mathrm{HCoV}$ $229 \mathrm{E}$ was reduced $70 \%$ within $30 \mathrm{~s}$ while $99.99 \%$ with 


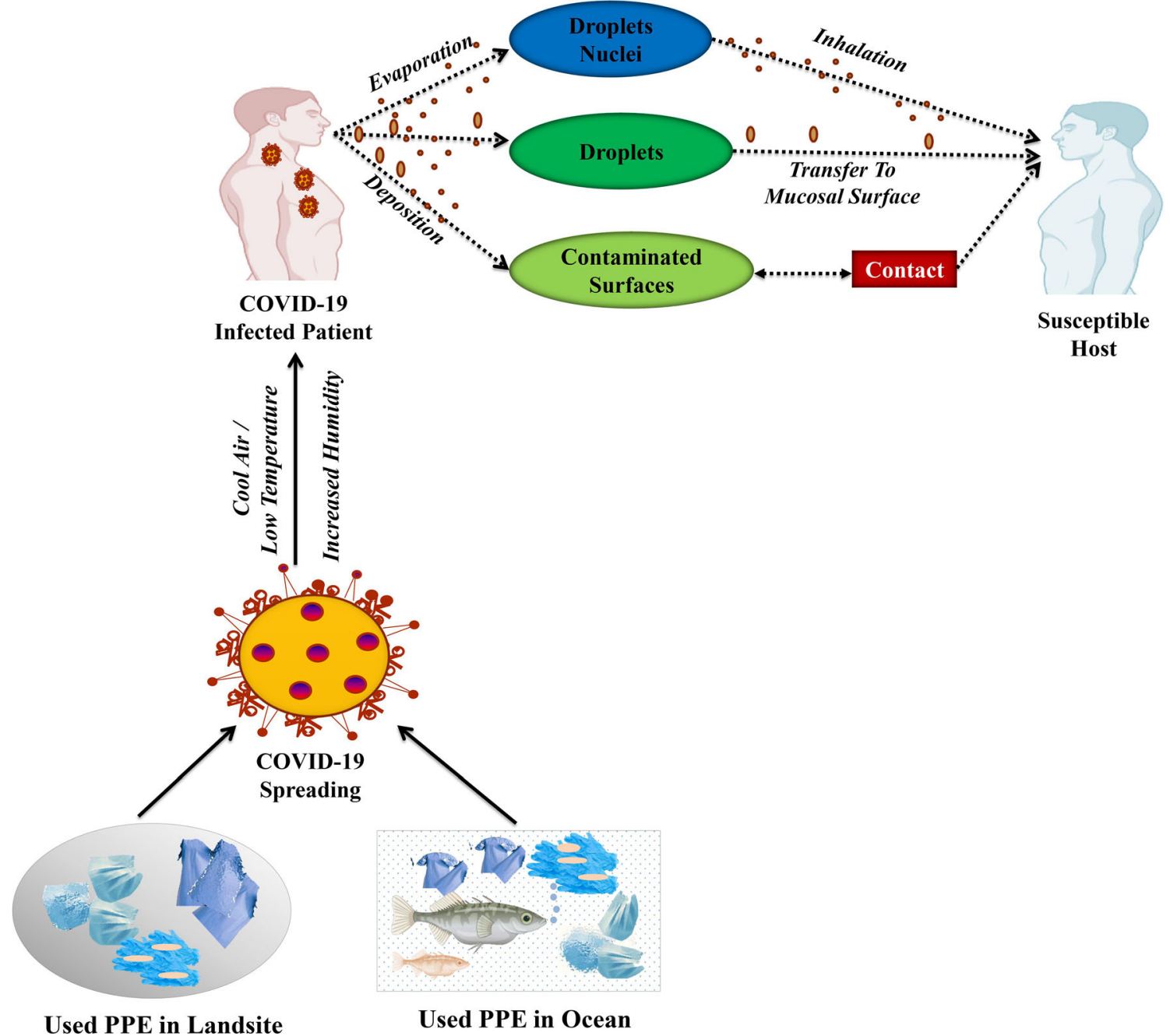

Fig. 2 Used PPE in the land site and ocean spreads COVID-19 transmission. Lower temperature and higher humidity are associated with COVID spreading. Besides, the transmission of COVID-19 might be increased though spreading droplets or touching contaminated place

using alcoholic sanitizer [87]. This study emphasizes the significance of proper hygiene and disinfection to prevent and manage infectious diseases like COVID-19.

\section{Environmental Surface}

The evidence on the features of such viruses is still limited, particularly if only COVID-19 is considered. The surface survival of the virus poses a threat to environmental and public health. If hospitals, operation theaters, and clean waiting rooms are taken into account, it is a much greater problem, particularly in the COVID departments. It may be essential to sanitize clinical settings to understand how the virus acts in contact with various surfaces and disinfectants [88]. In hospital operating rooms, instruments are used only for a specific purpose, but transferring vehicles could be another sources of contamination [89]. The existence of $\mathrm{CoV}$ in a hospital for COVID-19 patients was assessed by Ong et al. [90]. The existence is also found in the toilet bowl and the sink, but the air was free from $\mathrm{CoV}$ after cleaning the room. Depending on the surface properties, the survival time of $\mathrm{CoV}$ found to vary, the less porous such as plastic and steel, are by far the worst because they retain droplets less quickly, retaining the active virus. Besides, the amount of air in the rooms and the humidity may be influenced by the various environmental factors [3]. Transmission of aerosols and surface viruses is also possible since they can remain viable and contagious for hours or even days [3]. Kampf et al. [4] reported that $\mathrm{CoV}$ would live on surfaces for up to 9 days and that $0.1 \%$ sodium hypochlorite or $62-71 \%$ ethanol for $1 \mathrm{~min}$ should be used as a surface disinfectant. In poor ventilation settings, viral particles less than $0.1 \mu \mathrm{m}$ in size can remain in the atmosphere as a secondary aerosol. Studies suggest that up to 2 million droplets may be emitted into the air from a sneeze, less than a million from a cough, and about 3000 from speaking out loud. If greater than $100 \mu \mathrm{m}$, the droplets expelled 
from the respiratory tract from a height of $2 \mathrm{~m}$ fall on flat surfaces in 3-6 s and hit around $1.5 \mathrm{~m}$ horizontally, then evaporate easily, dry, and become solid substance. This substance achieves the size of 2-3 $\mu \mathrm{m}$ [88]. The importance of well ventilated environments for the prevention of SARSCoV2 infection has still not been addressed at length, and while viral particles have not been adequately tested for their ability to attain hazardous concentrations from distances in confined environments, improved ventilation in the atmosphere is thought to minimize the transmission of infection of airborne diseases.

\section{Climatic Alterations}

No scientific study to date can conclude that COVID-19 will drop dramatically after the warm season begins. More time is required to forecast the COVID-19 decline [91]. Several studies assumed that common weather patterns in places where COVID-19 has suffered the most [92]. It is less prevalent in the populations of countries in the east and west of the globe. On the other hand, it is highly prevalent in north and south regions which supported a pattern for the prediction of a disease outbreak [93]. There was found a good similarity of average temperature and relative humidity in Wuhan city in January 2020 with other affected places of China in February 2020 [94]. At meteorological stations, the temperature was between 4 and $9{ }^{\circ} \mathrm{C}$. But it was 5 to $11^{\circ} \mathrm{C}$ in the urban areas due to climate factors [95]. It can be expected that with the start of summer in the COVID-19 northern hemisphere, it will be influenza-like in the tropic and transmit simultaneously in the southern hemisphere [96].

\section{Medical Wastes of COVID-19 and Natural Habitats}

During this COVID pandemic, WHO strongly recommends using personal protective equipment (PPE) including N95 respirator mask, gloves, gown, face shield, and goggles [97]. Different types of polymers such as latex, polyurethane, nitrile rubber, neoprene, and polyvinyl chloride are used to make PPE [98]. These PPEs are liquid resistant and long-lasting that is why they are not fully ruined from the environment after discarding. A survey performed in Hong Kong by Ocean Asia NGO in January 2020 reveals that about 7 million people use masks (one or couple), gloves as well as hand sanitizers regularly because of COVID-19 [99]. Therefore, the amount of used PPE is increasing day by day and the environment becomes polluted. Another study confirmed that natural habitats both inland and ocean may face threats and sometimes ocean fishes take waste materials as food which may lead to their deaths [100]. The study revealed by WHO predicts a monthly demand of 89 million masks, 76 million gloves, and 1.6 million goggles for the COVID-19 response [101]. Infectious waste is not limited to hospitals alone, as people with mild or without symptoms often create virus-laden waste. Since the virus can survive for hours to days in cardboard, plastic, and metals, as seen, indiscriminately tossing or wasting such waste can risk the health of workers associated with waste control. In developed nations, where waste management employees are not provided with adequate PPE, the condition may become much more serious. In these nations, rag pickers and unofficial waste pickers are now in the high-risk zone of being contaminated by virus-laden waste. Millions of peoples in developing countries are devoid of waste collection and disposal facilities [102]. It is very urgent for developing country to ensure minimum health safety issues in waste collection, transportation, and disposal. Other major limitations are the lack of technological expertise as well as other scientific tools and economic supports to handle waste in a developing country.

The WHO describes the waste created by medical institutions during any medical operation as biomedical and health care waste (BMW) [103]. These medical practices include diagnosis and preventive, curative, and palliative therapies in veterinary and human medicine. The BMW contains sharp, contagious, pathological, chemical, pharmaceutical, and radioactive waste. It consists of non-hazardous waste $(85 \%)$ and hazardous waste (15\%), $10 \%$ of which is infectious waste, and $5 \%$ of which is chemical or radioactive waste [104]. In addition to the risk of contact transmission, BMW's poor handling conditions can cause negative environmental impacts, like contamination of soil and groundwater, the destruction of desirable microbes in septic systems, and physical injury by sharps items [105]. The latest reports of outbreaks of SARS-CoV, Ebola, and MERS-CoV illnesses demonstrate the need for safe handling of biomedical and health care waste for infection control practices. Awareness and knowledge can be a magic solution for better handling COVID-waste, so the government, local authorities, and waste management facilities need to initiate the awareness campaign to connect with people directly through digital and print media.

\section{COVID-19 and Neurological Disorders}

SARS-CoV2 is significantly associated with brain infection and recent evidence links COVID-19 to neurological disorders [106]. In the context of emerging research, COVID-19 infection can exacerbate the clinical spectrum of manifested neurological diseases. Furthermore, patients with AD, PD, and MS are frequently affected by $\mathrm{CoV}$ and are in the highrisk category [107]. SARS-CoV2 infection is also responsible for increasing the expression of inflammatory markers such as interleukin (IL)-1, IL-6, IL-10, and tumor necrosis factor alpha (TNF- $\alpha$ ) which contribute to microglial activation. Activated microglia eventually progress the neurodegenerative disorders including $\mathrm{AD}$, PD, and MS (Fig. 3) [108]. 


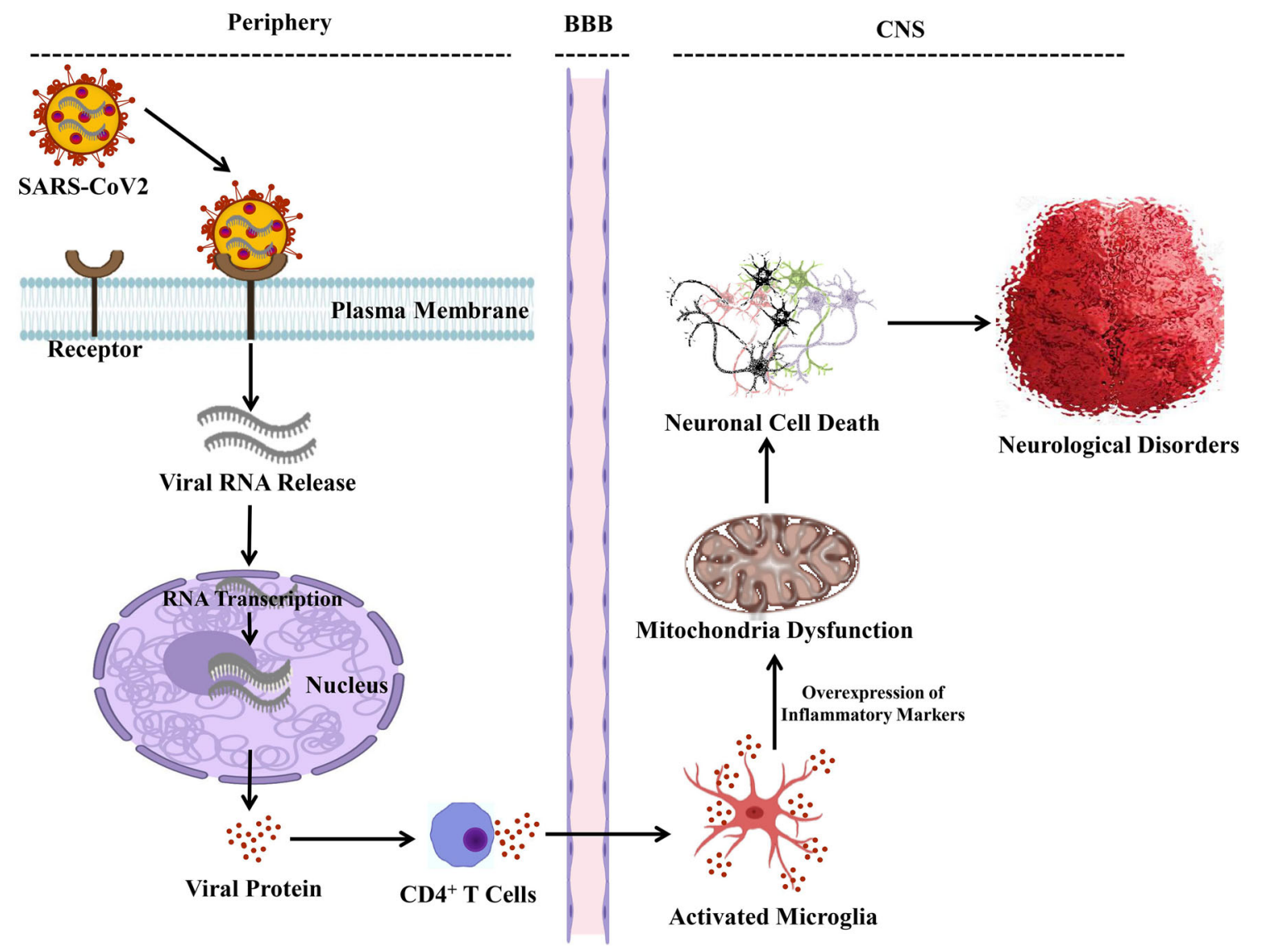

Fig. 3 Neurological disorders triggered by SARS-CoV2. At first, SARSCoV2 enters into the host cell and releases viral RNA which, in turn, aggregates proteins into $\mathrm{CD} 4^{+} \mathrm{T}$ cells. $\mathrm{CD} 4^{+} \mathrm{T}$ cells active microglia and produce elevated level of pro-inflammatory markers and these

markers accelerate mitochondrial dysfunction and neuronal death resulting in progression of neurological disorders. BBB, blood-brain barrier; CNS, central nervous system

\section{COVID-19 and Dementia Vulnerability}

Dementia mainly $\mathrm{AD}$ has appeared as a pandemic condition among the aging population [109]. Henceforth, managing this widely occurring disorder in the COVID-19 pandemic is raising some concerns. Firstly, a combination of two major risk factors including dementia and age plays role in the mortality in COVID-19 affected patients. Secondly, severe effects of concomitant dementia and COVID-19 pandemic including the effect of the quarantine and social distancing on neurocognitive functions of these vulnerable individuals need to be further studied. Indeed, following SARS-CoV2 infection, elderly people are more vulnerable to mortality. It has been estimated that the average age for all COVID-19-associated death is 81 years, and the case fatality rate in individuals aged $\geq 80$ years is over $20 \%$ [110]. Nonetheless, a limited number of reports have particularly focused on individuals aged $\geq 80$ years and insufficient data are available for COVID-19 in older individuals [111-113]. In addition, these studies were carried out in older individuals without dementia. In this population, Covino et al. [114] revealed a risk stratification when two major risk factors dementia and age are coexisting [114]. In a different study in central Italy, it was observed that death risk might not be age-dependent, while severe dementia might be an associated risk factor in these individuals [114]. Moreover, Bianchetti et al. [115] evaluated the clinical presentation, outcomes, and prevalence of dementia among patients who were hospitalized due to SARS-CoV2 infection. Findings from 627 hospitalized individuals in Northern Italy were retrospectively studied and it was observed that individuals affected by dementia presented increased mortality (around $40 \%$ ) as compared to individuals without dementia [115]. Collectively, these findings indicate that dementia might be a crucial risk factor for mortality in patients with COVID-19, particularly in case of late-stage dementia (Fig. 1).

\section{COVID-19 and Parkinson's Disease Vulnerability}

There is a link between COVID-19 and movement disorders including PD. Over 2 decades ago, it was revealed that there was an existence of antibodies against $\mathrm{CoV}$ in the cerebrospinal fluid of PD individuals [116]. Furthermore, CoVs can reach brain via the nasal cavity, which can eventually lead to hyposmia/anosmia [117]. Hyposmia is a usual premotor characteristic of PD and that olfactory bulb is the primary target of 
pathological alpha-synuclein deposition [118], which may be more than just a coincidence. Stoessl et al. [119] reported that still there are no proof that individuals with movement disorders are more prone towards $\mathrm{CoV}$ infection, in comparison with the patients with similar age and comorbidities [119]. Fasano et al. [120] mentioned the predictors/features of COVID-19 infection and consequences in PD patients in a different study in Milan, Italy. These researchers detected 105 PD individuals, 73 probable and 32 confirmed COVID-19 cases. As per their findings, COVID-19 risk, mortality, and morbidity in individuals with mild to moderate PD do not vary as compared to the general people [120]. Furthermore, in Japan, individuals with parkinsonism hospitalized for pneumonia experienced lower frequency of in-hospital mortality in comparison with sex- and agematched individuals $[121,122]$. In contrast, it was observed in a small number of PD individuals of older age with extended disease duration were mainly vulnerable to COVID-19 infection, along with a significantly elevated mortality rate [123]. Collectively, these results indicate that even though PD individuals might be a specifically susceptible population for ageassociated target, respiratory muscle rigidity associated with the disease, and existence of multiple comorbidities, PD does not elevate the risk of being infected via SARS-CoV2 and development of COVID-19.

\section{COVID-19 and Multiple Sclerosis Vulnerability}

MS might exhibit a particular interest to people because of the immunological nature of the disease and the clinical management by disease-modifying therapies (DMTs) that can change the immune responses, which can eventually elevate the vulnerability of COVID-19. Primary detection of possible risk factors is important to select a particular approach regarding the clinical management of these critical individuals throughout the COVID-19 pandemic. The link between MS and COVID-19 is complex. CoV family has been studied for a potential link with MS, and in recent times it has been utilized to develop a mouse model of MS [124]. Worldwide, it is a difficult task for neurologists to classify the risk of viral infection in patients with MS, particularly the individuals receiving immunomodulatory or immunosuppressant therapy. Even though it has been reported that MS individuals hypothetically might possess an elevated risk towards the infections as compared to the general people; however, still there is a debate whether MS individuals are at greater risk towards SARSCoV2 infection and to develop COVID-19. Willis et al. [124] considered 3 relevant articles to answer these questions. Among them, via utilizing 2 large databases with an extended follow-up time, the first study focused to distinguish the infection risk of MS individuals as compared to a group of individuals without MS $[124,125]$. As per the findings, patients with MS were generally at an elevated risk of infections, and that needed hospitalization.
On the other hand, the second study examined the risk of severe infections related to commonly used DMTs and rituximab (i.e., which was found to be frequently used in MS) [124, 126]. Interestingly, DMTs-treated MS individuals were generally at an elevated risk of infections, while the use of rituximab was linked with the highest rate of severe infections [124]. The link between the risk of infections and MS DMTs was assessed in a population-based retrospective cohort study [127]. In addition, their main findings confirmed that the introduction to a second-generation DMT was linked with an elevated risk, whereas the first generation was not related. Louapre et al. [128] revealed that male sex, progressive MS, EDSS, and comorbidities such as obesity, diabetes, and pulmonary and cardiovascular diseases were found as risk factors [128]. Nevertheless, in their univariate analysis, use of DMTs was not linked with the severity of SARS-CoV2 infection containing a lower risk of hospitalization [128]. Collectively, these results indicate that even though primarily it was identified that there is an elevated risk of COVID-19 infection in individuals with MS, but still there is a debate regarding the estimated risk for the MS individuals.

\section{Conclusion}

In this review, we highlight the possible meteorological parameters, which may contribute to reducing the spread of SARS-COV2. In order to control the outbreak of COVID19 , further measures should be taken to abate the transmission of this life-threatening virus. Although, the genomics and modes of transmission are controversial till now. As a result, we find out the genetic diversity as well as the mode of the transmission behind the pathogenesis of COVID-19. All persons should strongly maintain social distancing and wear PPE. Persons coming from other countries or individuals who travel in COVID-19 infected areas should maintain 14 days quarantine. Patients who are critically ill need to contact the doctor and should be given sufficient medical treatment. Additionally, environmental factors are significantly associated with COVID-19 pathogenesis and neurological disorders. Further studies are needed to understand the exact mechanism related to the pathogenesis of neurological disorders.

Acknowledgments This research was funded by the Deanship of Scientific Research at Princess Nourah bint Abdulrahman University through the Fast-track Research Funding Program. This work was supported by King Saud University, Deanship of Scientific Research, College of Science Research Center.

Authors' Contributions MSU and MFH conceived the original idea and designed the outlines of the study. SH, MFH, MTK, and MGU wrote the draft of the manuscript. MFH and MSU prepared the figures of the manuscript. MJ, MIIW, TB, MNB-J, MMA-D, and LA involved in the revision and improved the manuscript. All authors read and approved the final submitted version of the manuscript. 


\section{Compliance with Ethical Standards}

Competing Interests The authors declare that they have no competing interests.

\section{References}

1. Guo YR, Cao QD, Hong ZS et al (2020) The origin, transmission and clinical therapies on coronavirus disease 2019 (COVID-19) outbreak- an update on the status. Mil Med Res 7. https://doi.org/ 10.1186/s40779-020-00240-0

2. Behl T, Kaur I, Bungau S, Kumar A, Uddin MS, Kumar C, Pal G, Sahil et al (2020) The dual impact of ACE2 in COVID-19 and ironical actions in geriatrics and pediatrics with possible therapeutic solutions. Life Sci 257:118075. https://doi.org/10.1016/j.lfs.2020.118075

3. van Doremalen N, Bushmaker T, Morris DH, Holbrook MG, Gamble A, Williamson BN, Tamin A, Harcourt JL et al (2020) Aerosol and surface stability of SARS-CoV-2 as compared with SARS-CoV-1. N Engl J Med 382:1564-1567. https://doi.org/10. 1056/NEJMc2004973

4. Kampf G, Todt D, Pfaender S, Steinmann E (2020) Persistence of coronaviruses on inanimate surfaces and their inactivation with biocidal agents. J Hosp Infect 104:246-251

5. Martinez ME (2018) The calendar of epidemics: Seasonal cycles of infectious diseases. PLoS Pathog 14:e1007327. https://doi.org/ 10.1371/journal.ppat.1007327

6. Shaman J, Pitzer VE, Viboud C, Grenfell BT, Lipsitch M (2010) Absolute humidity and the seasonal onset of influenza in the continental United States. PLoS Biol 8:e1000316. https://doi.org/10. 1371/journal.pbio.1000316

7. Tan J, Mu L, Huang J, Yu S, Chen B, Yin J (2005) An initial investigation of the association between the SARS outbreak and weather: with the view of the environmental temperature and its variation. J Epidemiol Community Health 59:186-192. https:// doi.org/10.1136/jech.2004.020180

8. The Centre for Evidence-Based Medicine (2020) Do weather conditions influence the transmission of the coronavirus (SARS-CoV2)? Available at: https://www.cebm.net/covid-19/do-weatherconditions-influence-the-transmission-of-the-coronavirus-sarscov-2/. Accessed 18 Oct 2020

9. Chin AWH, Chu JTS, Perera MRA, Hui KPY, Yen HL, Chan MCW, Peiris M, Poon LLM (2020) Stability of SARS-CoV-2 in different environmental conditions. Lancet Mic 1:e10. https://doi. org/10.1016/s2666-5247(20)30003-3

10. Xie J, Zhu Y (2020) Association between ambient temperature and COVID-19 infection in 122 cities from China. Sci Total Environ 724:138201. https://doi.org/10.1016/j.scitotenv.2020.138201

11. Yao Y, Pan J, Liu Z, Meng X, Wang W, Kan H, Wang W (2020) No association of COVID-19 transmission with temperature or UV radiation in Chinese cities. Eur Respir J 55:2000517. https:// doi.org/10.1183/13993003.00517-2020

12. Ma Y, Zhao Y, Liu J, He X, Wang B, Fu S, Yan J, Niu J et al (2020) Effects of temperature variation and humidity on the death of COVID-19 in Wuhan, China. Sci Total Environ 724:138226. https://doi.org/10.1016/j.scitotenv.2020.138226

13. Leung K, Wu JT, Liu D, Leung GM (2020) First-wave COVID19 transmissibility and severity in China outside Hubei after control measures, and second-wave scenario planning: a modelling impact assessment. Lancet 395:1382-1393. https://doi.org/10. 1016/S0140-6736(20)30746-7

14. Price RHM, Graham C, Ramalingam S (2019) Association between viral seasonality and meteorological factors. Sci Rep 9:111. https://doi.org/10.1038/s41598-018-37481-y
15. Matías-Guiu J, Gomez-Pinedo U, Montero-Escribano P, GomezIglesias P, Porta-Etessam J, Matias-Guiu JA (2020) Should we expect neurological symptoms in the SARS-CoV-2 epidemic? Neurologia 35:170-175

16. Li YC, Bai WZ, Hashikawa T (2020) The neuroinvasive potential of SARS-CoV2 may play a role in the respiratory failure of COVID-19 patients. J Med Virol 92:552-555

17. Li K, Wohlford-Lenane C, Perlman S, Zhao J, Jewell AK, Reznikov LR, Gibson-Corley KN, Meyerholz DK et al (2015) Middle east respiratory syndrome coronavirus causes multiple organ damage and lethal disease in mice transgenic for human dipeptidyl peptidase 4. J Infect Dis 212:712-722. https://doi.org/ 10.1093/infdis/jiv499

18. Doobay MF, Talman LS, Obr TD, Tian X, Davisson RL, Lazartigues E (2007) Differential expression of neuronal ACE2 in transgenic mice with overexpression of the brain reninangiotensin system. Am J Phys Regul Integr Comp Phys 292: R373-R381. https://doi.org/10.1152/ajpregu.00292.2006

19. Rodriguez-Perez AI, Garrido-Gil P, Pedrosa MA, Garcia-Garrote M, Valenzuela R, Navarro G, Franco R, Labandeira-Garcia JL (2020) Angiotensin type 2 receptors: role in aging and neuroinflammation in the substantia nigra. Brain Behav Immun 87:256271. https://doi.org/10.1016/j.bbi.2019.12.011

20. WHO (2020) Coronavirus disease (COVID-2019) situation reports. https://www.who.int/emergencies/diseases/novelcoronavirus-2019/situation-reports. Accessed $25 \mathrm{Jul} 2020$

21. WHO (2020) COVID-19 weekly epidemiological update. Available at: https://www.who.int/docs/default-source/ coronaviruse/situation-reports/20201020-weekly-epi-update-10. pdf. Accessed 18 Oct 2020

22. Wu A, Peng Y, Huang B, Ding X, Wang X, Niu P, Meng J, Zhu Z et al (2020) Genome composition and divergence of the novel coronavirus (2019-nCoV) originating in China. Cell Host Microbe 27:325-328. https://doi.org/10.1016/j.chom.2020.02. 001

23. Kabir TM, Uddin MS, Hossain MF et al (2020) nCOVID-19 pandemic: from molecular pathogenesis to potential investigational therapeutics. Front Cell Dev Biol 8:616. https://doi.org/10. 3389/fcell.2020.00616

24. Chan JFW, Kok KH, Zhu Z, Chu H, To KKW, Yuan S, Yuen KY (2020) Genomic characterization of the 2019 novel humanpathogenic coronavirus isolated from a patient with atypical pneumonia after visiting Wuhan. Emerg Microbes Infect 9:221-236. https://doi.org/10.1080/22221751.2020.1719902

25. Song Z, Xu Y, Bao L, Zhang L, Yu P, Qu Y, Zhu H, Zhao W et al (2019) From SARS to MERS, thrusting coronaviruses into the spotlight. Viruses 11. https://doi.org/10.3390/v11010059

26. Cui J, Li F, Shi ZL (2019) Origin and evolution of pathogenic coronaviruses. Nat Rev Microbiol 17:181-192. https://doi.org/10. 1038/s41579-018-0118-9

27. Angeletti S, Benvenuto D, Bianchi M, Giovanetti M, Pascarella S, Ciccozzi M (2020) COVID-2019: The role of the nsp2 and nsp3 in its pathogenesis. J Med Virol 92:584-588. https://doi.org/10. 1002/jmv.25719

28. Zhang L, Shen F, Chen F, Lin Z (2020) Origin and evolution of the 2019 novel coronavirus. Clin Infect Dis 71:882-883. https:// doi.org/10.1093/cid/ciaa112

29. Cascella M, Rajnik M, Cuomo A et al (2020) Features, evaluation and treatment coronavirus (COVID-19). USA: StatPearls.

30. Xu J, Zhao S, Teng T et al (2020) Systematic comparison of two animal-to-human transmitted human coronaviruses: SARS-CoV2 and SARS-CoV. Viruses 12. https://doi.org/10.3390/v12020244

31. Shanker AK, Bhanu D, Alluric A et al (2020) Whole genome sequence analysis and homology modelling of a $3 \mathrm{C}$ like peptidase and a non-structural protein 3 of the SARS-CoV-2 shows protein ligand interaction with an aza-peptide and a noncovalent lead 
inhibitor with possible antiviral properties. New J Chem 44:92029212. https://doi.org/10.1039/d0nj00974a

32. Hossain MF, Hasana S, Mamun AA et al (2020) COVID-19 outbreak: pathogenesis, current therapies, and potentials for future management. Front Pharmacol 11:1-25. https://doi.org/10.3389/ fphar.2020.563478

33. Phan T (2020) Genetic diversity and evolution of SARS-CoV-2. Infect Genet Evol 81:104260. https://doi.org/10.1016/j.meegid. 2020.104260

34. Zhou P, Lou YX, Wang XG et al (2020) A pneumonia outbreak associated with a new coronavirus of probable bat origin. Nature 579:270-273. https://doi.org/10.1038/s41586-020-2012-7

35. Xu X, Chen P, Wang J, Feng J, Zhou H, Li X, Zhong W, Hao P (2020) Evolution of the novel coronavirus from the ongoing Wuhan outbreak and modeling of its spike protein for risk of human transmission. Sci China Life Sci 63:457-460. https://doi. org/10.1007/s11427-020-1637-5

36. Hulswit RJG, Lang Y, Bakkers MJG, Li W, Li Z, Schouten A, Ophorst B, van Kuppeveld FJM et al (2019) Human coronaviruses OC43 and HKU1 bind to 9-O-acetylated sialic acids via a conserved receptor-binding site in spike protein domain A. Proc Natl Acad Sci U S A 116:2681-2690. https://doi.org/10.1073/pnas.1809667116

37. Walls AC, Park YJ, Tortorici MA et al (2020) Structure, function, and antigenicity of the SARS-CoV-2 spike glycoprotein. Cell 181: 281-292.e6. https://doi.org/10.1016/j.cell.2020.02.058

38. Sun Z, Thilakavathy K, Kumar SS, He G, Liu SV (2020) Potential factors influencing repeated SARS outbreaks in China. Int $\mathrm{J}$ Environ Res Public Health 17:1633. https://doi.org/10.3390/ ijerph17051633

39. Chan JFW, Yuan S, Kok KH, To KKW, Chu H, Yang J, Xing F, Liu J et al (2020) A familial cluster of pneumonia associated with the 2019 novel coronavirus indicating person-to-person transmission: a study of a family cluster. Lancet 395:514-523. https://doi. org/10.1016/S0140-6736(20)30154-9

40. Kumar R, Srivastava JK, Singh R, Siddiqui MH, Mansouri RA, Abdulhakim JA, Bin-Jumah MN, Alkahtani S et al (2020) Available compounds with therapeutic potential against COVID-19: Antimicrobial therapies, supportive care, and probable vaccines. Front Pharmacol 11:1-14. https://doi.org/10.3389/fphar.2020.582025

41. Shen K, Yang Y, Wang T et al (2020) Diagnosis, treatment, and prevention of 2019 novel coronavirus infection in children: experts' consensus statement. World J Pediatr 16:223-231. https:// doi.org/10.1007/s12519-020-00343-7

42. Holshue ML, DeBolt C, Lindquist S, Lofy KH, Wiesman J, Bruce H, Spitters C, Ericson K et al (2020) First case of 2019 novel coronavirus in the United States. N Engl J Med 382:929-936. https://doi.org/10.1056/NEJMoa2001191

43. Zhu H, Wang L, Fang $\mathrm{C}$ et al (2020) Clinical analysis of 10 neonates born to mothers with 2019-nCoV pneumonia. Transl Pediatr 9:51-60. https://doi.org/10.21037/tp.2020.02.06

44. Li JPO, Lam DSC, Chen Y, Ting DSW (2020) Novel Coronavirus disease 2019 (COVID-19): the importance of recognising possible early ocular manifestation and using protective eyewear. Br J Ophthalmol 104:297-298. https://doi.org/10.1136/bjophthalmol2020-315994

45. Dehghani R, Kassiri H (2020) A brief review on the possible role of houseflies and cockroaches in the mechanical transmission of coronavirus disease 2019 (Covid-19). Arch Clin Infect Dis 15: e102863. https://doi.org/10.5812/archcid.102863

46. Bin SY, Heo JY, Song MS, Lee J, Kim EH, Park SJ, Kwon HI, Kim $S$ et al (2015) Environmental contamination and viral shedding in MERS patients during MERS-CoV outbreak in South Korea. Clin Infect Dis 62:755-760. https://doi.org/10.1093/cid/civ1020

47. Eslami H, Ehrampoush MH, Falahzadeh H, Hematabadi PT, Khosravi R, Dalvand A, Esmaeili A, Taghavi M et al (2018) Biodegradation and nutrients removal from greywater by an integrated fixed-film activated sludge (IFAS) in different organic loadings rates. AMB Express 8:3. https://doi.org/10.1186/s13568017-0532-9

48. Bhattacharjee S (2020) Statistical investigation of relationship between spread of coronavirus disease (COVID-19) and environmental factors based on study of four mostly affected places of China and five mostly affected places of Italy. Available at: https:// arxiv.org/abs/2003.11277. Accessed 18 Oct 2020

49. Chen N, Zhou M, Dong X, Qu J, Gong F, Han Y, Qiu Y, Wang J et al (2020) Epidemiological and clinical characteristics of 99 cases of 2019 novel coronavirus pneumonia in Wuhan, China: a descriptive study. Lancet 395:507-513. https://doi.org/10.1016/ S0140-6736(20)30211-7

50. Huang C, Wang Y, Li X, Ren L, Zhao J, Hu Y, Zhang L, Fan G et al (2020) Clinical features of patients infected with 2019 novel coronavirus in Wuhan, China. Lancet 395:497-506. https://doi. org/10.1016/S0140-6736(20)30183-5

51. Wang D, Hu B, Hu C, Zhu F, Liu X, Zhang J, Wang B, Xiang H et al (2020) Clinical characteristics of 138 hospitalized patients with 2019 novel coronavirus-infected pneumonia in Wuhan, China. JAMA 323:1061-1069. https://doi.org/10.1001/jama. 2020.1585

52. Xiao F, Tang M, Zheng X et al (2020) Evidence for gastrointestinal infection of SARS-CoV-2. Gastroenterology 158:18311833.e3. https://doi.org/10.1053/j.gastro.2020.02.055

53. WHO (2020) Water, sanitation, hygiene, and waste management for SARS-CoV-2, the virus that causes COVID-19. Available at: https://www.who.int/publications/i/item/WHO-2019-nCoV-IPCWASH-2020.4. Accessed 18 Oct 2020

54. Qu G, Li X, Hu L, Jiang G (2020) An imperative need for research on the role of environmental factors in transmission of novel coronavirus (COVID-19). Environ Sci Technol 54:3730-3732. https://doi.org/10.1021/acs.est.0c01102

55. Lodder W, de Roda Husman AM (2020) SARS-CoV-2 in wastewater: potential health risk, but also data source. Lancet Gastroenterol Hepatol 5:533-534. https://doi.org/10.1016/ S2468-1253(20)30087-X

56. Medema G, Heijnen L, Elsinga G, et al (2020) Presence of SARSCoronavirus-2 in sewage. medRxiv. https://doi.org/10.1101/2020. 03.29.20045880

57. Naddeo V, Liu H (2020) Editorial Perspectives: 2019 novel coronavirus (SARS-CoV-2): what is its fate in urban water cycle and how can the water research community respond? Environ Sci Water Res Technol 6:1213-1216. https://doi.org/10.1039/ d0ew90015j

58. Seymour N, Yavelak M, Christian C et al (2020) COVID-19 FAQ for food service: receiving and food packaging. Available at: https://www.edis.ifas.ufl.edu/fs337. Accessed 18 Oct 2020

59. Seymour N, Yavelak M, Christian C et al (2020) COVID-19 and food safety FAQ: is coronavirus a food safety issue? Available at: https://edis.ifas.ufl.edu/fs341. Accessed 18 Oct 2020

60. Eslami H, Marzban A, AkramiMohajeri F, Rezaei Z, Fard MR (2020) Students' knowledge and attitude of hygiene and food safety at Shahid Sadoughi University of Medical Sciences in Yazd Iran - Journal of Community Health Research. J Community Health Res 4:159-167

61. Chan JFW, Yip CCY, To KKW et al (2020) Improved molecular diagnosis of COVID-19 by the novel, highly sensitive and specific COVID-19-RdRp/Hel real-time reverse transcription-polymerase chain reaction assay validated in vitro and with clinical specimens. J Clin Microbiol 58. https://doi.org/10.1128/JCM.00310-20

62. WHO (2020) Report of the WHO-China Joint Mission on Coronavirus Disease 2019 (COVID-19). Available at: https://www. who.int/publications/i/item/report-of-the-who-china-joint-missionon-coronavirus-disease-2019-(covid-19). Accessed 18 Oct 2020 
63. Young BE, Ong SWX, Kalimuddin S, Low JG, Tan SY, Loh J, Ng OT, Marimuthu K et al (2020) Epidemiologic features and clinical course of patients infected with SARS-CoV-2 in Singapore. JAMA 323:1488-1494. https://doi.org/10.1001/jama.2020.3204

64. Rothe C, Schunk M, Sothmann P, Bretzel G, Froeschl G, Wallrauch C, Zimmer T, Thiel V et al (2020) Transmission of 2019-NCOV infection from an asymptomatic contact in Germany. N Engl J Med 382:970-971

65. Hoehl S, Rabenau H, Berger A, Kortenbusch M, Cinatl J, Bojkova D, Behrens P, Böddinghaus B et al (2020) Evidence of SARS$\mathrm{CoV}-2$ infection in returning travelers from Wuhan, China. N Engl J Med 382:1278-1280

66. ECDC (2020) Novel coronavirus (SARS-CoV-2). Available at: https://www.ecdc.europa.eu/sites/default/files/documents/ COVID-19-Discharge-criteria.pdf. Accessed 18 Oct 2020

67. Lowen AC, Steel J (2014) Roles of humidity and temperature in shaping influenza seasonality. J Virol 88:7692-7695. https://doi. org/10.1128/jvi.03544-13

68. Ng S, Gordon A (2015) Influenza burden and transmission in the tropics. Curr Epidemiol Rep 2:89-100. https://doi.org/10.1007/ s40471-015-0038-4

69. CDC (2020) Keep Children Healthy during the COVID-19 Pandemic. Available at: https://www.cdc.gov/coronavirus/2019ncov/daily-life-coping/children.html. Accessed 18 Oct 2020

70. Dopico XC, Evangelou M, Ferreira RC, Guo H, Pekalski ML, Smyth DJ, Cooper N, Burren OS et al (2015) Widespread seasonal gene expression reveals annual differences in human immunity and physiology. Nat Commun 6:7000. https://doi.org/10.1038/ncomms8000

71. Baekelandt S, Milla S, Cornet V et al (2020) Seasonal simulated photoperiods influence melatonin release and immune markers of pike perch Sander lucioperca. Sci Rep 10:1-10. https://doi.org/10. 1038/s41598-020-59568-1

72. Hart PH, Gorman S (2013) Exposure to UV wavelengths in sunlight suppresses immunity. to what extent is UV-induced vitamin D3 the mediator responsible? Clin Biochem Rev 34:3-13

73. Rondanelli M, Miccono A, Lamburghini S et al (2018) Self-care for common colds: the pivotal role of vitamin D, vitamin C, zinc, and echinacea in three main immune interactive clusters (physical barriers, innate and adaptive immunity) involved during an episode of common colds - practical advice on dosages an. Evid Based Complement Alternat Med 2018. https://doi.org/10.1155/ 2018/5813095

74. Zhao D, Yao F, Wang L, Zheng L, Gao Y, Ye J, Guo F, Hui Zhao RG (2020) A comparative study on the clinical features of COVID-19 pneumonia to other pneumonias. Clin Infect Dis 71: 756-761. https://doi.org/10.1093/cid/ciaa247

75. Jiang X, Rayner S, Luo MH (2020) Does SARS-CoV-2 has a longer incubation period than SARS and MERS? J Med Virol 92:476-478. https://doi.org/10.1002/jmv.25708

76. Nishiura H, Linton NM, Akhmetzhanov AR (2020) Serial interval of novel coronavirus (COVID-19) infections. Int J Infect Dis 93: 284-286. https://doi.org/10.1016/j.ijid.2020.02.060

77. Kamel Boulos MN, Geraghty EM (2020) Geographical tracking and mapping of coronavirus disease COVID-19/severe acute respiratory syndrome coronavirus 2 (SARS-CoV-2) epidemic and associated events around the world: How 21st century GIS technologies are supporting the global fight against outbr. Int J Health Geogr 19. https://doi.org/10.1186/s12942-020-00202-8

78. Long Y, Hu T, Liu L, Chen R, Guo Q, Yang L, Cheng Y, Huang J et al (2020) Effectiveness of N95 respirators versus surgical masks against influenza: a systematic review and meta-analysis. J Evid Based Med 13:93-101. https://doi.org/10.1111/jebm.12381

79. Wang X, Pan Z, Cheng Z (2020) Association between 2019nCoV transmission and N95 respirator use. J Hosp Infect 105: 104-105. https://doi.org/10.1016/j.jhin.2020.02.021
80. Yu ITS, Li Y, Wong TW, Tam W, Chan AT, Lee JHW, Leung DYC, Ho T (2004) Evidence of airborne transmission of the severe acute respiratory syndrome virus. N Engl J Med 350:17311739. https://doi.org/10.1056/NEJMoa032867

81. Olsen SJ, Chang H-L, Cheung TY-Y, Tang AFY, Fisk TL, Ooi SPL, Kuo HW, Jiang DDS et al (2003) Transmission of the severe acute respiratory syndrome on aircraft. N Engl J Med 349:24162422. https://doi.org/10.1056/NEJMoa031349

82. La Rosa G, Fratini M, Libera SD et al (2013) Viral infections acquired indoors through airborne, droplet or contact transmission. Ann Ist Super Sanita 49. https://doi.org/10.4415/ANN_13 02_03

83. Vogt TM, Guerra MA, Flagg EW, Ksiazek TG, Lowther SA, Arguin PM (2006) Risk of severe acute respiratory syndromeassociated coronavirus transmission aboard commercial aircraft. J Travel Med 13:268-272. https://doi.org/10.1111/j.1708-8305. 2006.00048.x

84. Somogyi R, Vesely AE, Azami T, Preiss D, Fisher J, Correia J, Fowler RA (2004) Dispersal of respiratory droplets with open vs closed oxygen delivery masks: Implications for the transmission of severe acute respiratory syndrome. Chest 125:1155-1157. https://doi.org/10.1378/chest.125.3.1155

85. Li Y, Huang X, Yu ITS, Wong TW, Qian H (2005) Role of air distribution in SARS transmission during the largest nosocomial outbreak in Hong Kong. Indoor Air 15:83-95. https://doi.org/10. 1111/j.1600-0668.2004.00317.x

86. Warnes SL, Little ZR, Keevil CW (2015) Human coronavirus $229 \mathrm{E}$ remains infectious on common touch surface materials. MBio 6:e01697-e01615. https://doi.org/10.1128/mBio.01697-15

87. Geller C, Varbanov M, Duval RE (2012) Human coronaviruses: Insights into environmental resistance and its influence on the development of new antiseptic strategies. Viruses 4:3044-3068

88. Fiorillo L, Cervino G, Matarese M, D'Amico C, Surace G, Paduano V, Fiorillo MT, Moschella A et al (2020) COVID-19 surface persistence: a recent data summary and its importance for medical and dental settings. Int J Environ Res Public Health 17. https://doi.org/10.3390/ijerph17093132

89. Dexter F, Parra MC, Brown JR, Loftus RW (2020) Perioperative COVID-19 defense: an evidence-based approach for optimization of infection control and operating room management. Anesth Analg:37-42. https://doi.org/10.1213/ANE.0000000000004829

90. Ong SWX, Tan YK, Chia PY, Lee TH, Ng OT, Wong MSY, Marimuthu K (2020) Air, surface environmental, and personal protective equipment contamination by severe acute respiratory syndrome coronavirus 2 (SARS-CoV-2) from a symptomatic patient. JAMA 323:1610-1612. https://doi.org/10.1001/jama.2020. 3227

91. Mahase E (2020) Covid-19: 90\% of cases will hit NHS over nine week period, chief medical officer warns. BMJ 368:m918. https:// doi.org/10.1136/bmj.m918

92. Lipsitch M, Swerdlow DL, Finelli L (2020) Defining the epidemiology of covid-19 — studies needed. N Engl J Med 382:1194 1196. https://doi.org/10.1056/NEJMp2002125

93. Gates B (2020) Responding to Covid-19 - a once-in-a-century pandemic? N Engl J Med 382:1677-1679. https://doi.org/10. 1056/NEJMp2003762

94. Vetter P, Eckerle I, Kaiser L (2020) Covid-19: a puzzle with many missing pieces. BMJ 368:m627. https://doi.org/10.1136/bmj.m627

95. Sajadi MM, Habibzadeh P, Vintzileos A, Shokouhi S, MirallesWilhelm F, Amoroso A (2020) Temperature and latitude analysis to predict potential spread and seasonality for COVID-19. SSRN Electron J. https://doi.org/10.2139/ssrn.3550308

96. Anderson RM, Heesterbeek H, Klinkenberg D, Hollingsworth TD (2020) How will country-based mitigation measures influence the course of the COVID-19 epidemic? Lancet 395:931-934 
97. Ng K, Poon BH, Kiat Puar TH, Shan Quah JL, Loh WJ, Wong YJ, Tan TY, Raghuram J (2020) COVID-19 and the risk to health care workers: a case report. Ann Intern Med 172:766-767. https://doi. org/10.7326/L20-0175

98. Kwon KT, Ko JH, Shin $\mathrm{H}$ et al (2020) Drive-through screening center for covid-19: a safe and efficient screening system against massive community outbreak. J Korean Med Sci 35. https://doi. org $/ 10.3346 / \mathrm{jkms} .2020 .35 . \mathrm{e} 123$

99. Saadat S, Rawtani D, Hussain CM (2020) Environmental perspective of COVID-19. Sci Total Environ 728:138870. https://doi.org/ 10.1016/j.scitotenv.2020.138870

100. Hellewell J, Abbott S, Gimma A, Bosse NI, Jarvis CI, Russell TW, Munday JD, Kucharski AJ et al (2020) Feasibility of controlling COVID-19 outbreaks by isolation of cases and contacts. Lancet Glob Health 8:e488-e496. https://doi.org/10.1016/S2214109X(20)30074-7

101. WHO (2020) Shortage of personal protective equipment endangering health workers worldwide. Available at: https:/www.who. int/news/item/03-03-2020-shortage-of-personal-protectiveequipment-endangering-health-workers-worldwide. Accessed 18 Oct 2020

102. Wilson D, Rodic L, Modak P, et al (2015) Global waste management outlook. In: global waste management outlook. USA: United Nations Environment Programme.

103. WHO (2020) Safe management of wastes from health-care activities. Available at: https:/www.who.int/water sanitation health/ publications/wastemanag/en/. Accessed 18 Oct 2020

104. Chartier Y, Emmanuel J, Pieper U et al (2014) Safe management of wastes from health-care activities, Switzerland: WHO.

105. Datta P, Mohi G, Chander J (2018) Biomedical waste management in India: critical appraisal. J Lab Physicians 10:006-014. https://doi.org/10.4103/jlp.jlp 8917

106. Papa SM, Brundin P, Fung VSC, Kang UJ, Burn DJ, Colosimo C, Chiang HL, Alcalay RN et al (2020) Impact of the COVID-19 pandemic on Parkinson's disease and movement disorders. Mov Disord 35:711-715. https://doi.org/10.1002/mds.28067

107. Ferini-Strambi L, Salsone M (2020) COVID-19 and neurological disorders: are neurodegenerative or neuroimmunological diseases more vulnerable? J Neurol 1:11. https://doi.org/10.1007/s00415020-10070-8

108. DosSantos MF, Devalle $S$, Aran V et al (2020) Neuromechanisms of SARS-CoV-2: a review. Front Neuroanat 14:37. https://doi.org/ 10.3389 /fnana.2020.00037

109. Fox NC, Petersen RC (2013) The G8 Dementia Research Summita starter for eight? Lancet 382:1968-1969. https://doi.org/10. 1016/S0140-6736(13)62426-5

110. Onder G, Rezza G, Brusaferro S (2020) Case-fatality rate and characteristics of patients dying in relation to COVID-19 in Italy. JAMA 323:1775-1776. https://doi.org/10.1001/jama.2020. 4683

111. Liu K, Chen Y, Lin R, Han K (2020) Clinical features of COVID19 in elderly patients: a comparison with young and middle-aged patients. J Infect 80:e14-e18. https://doi.org/10.1016/j.jinf.2020. 03.005

112. Leung C (2020) Risk factors for predicting mortality in elderly patients with COVID-19: a review of clinical data in China. Mech Ageing Dev 188:111255. https://doi.org/10.1016/j.mad. 2020.111255

113. Wang L, He W, Yu X, Hu D, Bao M, Liu H, Zhou J, Jiang H (2020) Coronavirus disease 2019 in elderly patients: characteristics and prognostic factors based on 4-week follow-up. J Infect 80: 639-645. https://doi.org/10.1016/j.jinf.2020.03.019

114. Covino M, De Matteis G, Santoro M et al (2020) Clinical characteristics and prognostic factors in COVID-19 patients aged $\geq 80$ years. Geriatr Gerontol Int 20:704-708. https://doi.org/10.1111/ ggi.13960

115. Bianchetti A, Rozzini R, Guerini F, Boffelli S, Ranieri P, Minelli G, Bianchetti L, Trabucchi M (2020) Clinical presentation of COVID19 in dementia patients. J Nutr Health Aging 24:560 562. https://doi.org/10.1007/s12603-020-1389-1

116. Fazzini E, Fleming J, Fahn S (1992) Cerebrospinal fluid antibodies to coronavirus in patients with Parkinson's disease. Mov Disord 7:153-158. https://doi.org/10.1002/mds.870070210

117. Antonini A, Leta V, Teo J, Chaudhuri KR (2020) Outcome of Parkinson's disease patients affected by COVID-19. Mov Disord 35:905-908

118. Braak H, Del Tredici K, Rüb U et al (2003) Staging of brain pathology related to sporadic Parkinson's disease. Neurobiol Aging 24: 197-211. https://doi.org/10.1016/S0197-4580(02)00065-9

119. Stoessl AJ, Bhatia KP, Merello M (2020) Movement disorders in the world of COVID-19. Mov Disord Clin Pract 7:355-356

120. Fasano A, Antonini A, Katzenschlager R, Krack P, Odin P, Evans AH, Foltynie T, Volkmann J et al (2020) Management of advanced therapies in Parkinson's disease patients in times of humanitarian crisis: the COVID-19 experience. Mov Disord Clin Pract 7:361-372

121. Papa SM, Brundin P, Fung VSC, Kang UJ, Burn DJ, Colosimo C, Chiang HL, Alcalay RN et al (2020) Impact of the COVID-19 pandemic on Parkinson's disease and movement disorders. Mov Disord Clin Pract 7:357-360

122. Jo T, Yasunaga H, Michihata N, Sasabuchi Y, Hasegawa W, Takeshima H, Sakamoto Y, Matsui H et al (2018) Influence of Parkinsonism on outcomes of elderly pneumonia patients. Parkinsonism Relat Disord 54:25-29. https://doi.org/10.1016/j. parkreldis.2018.03.028

123. Donadio V, Incensi A, Rizzo G, de Micco R, Tessitore A, Devigili G, del Sorbo F, Bonvegna S et al (2020) Skin biopsy may help to distinguish multiple system atrophy-parkinsonism from Parkinson's disease with orthostatic hypotension. Mov Disord 35:1649-1657. https://doi.org/10.1002/mds.28126

124. Willis MD, Robertson NP (2020) Multiple sclerosis and the risk of infection: considerations in the threat of the novel coronavirus, COVID-19/SARS-CoV-2. J Neurol 267:1567-1569. https://doi. org/10.1007/s00415-020-09822-3

125. Persson R, Lee S, Ulcickas Yood M, Wagner, USN, MC CAPTM, Minton N, Niemcryk S, Lindholm A, Evans AM et al (2020) Infections in patients diagnosed with multiple sclerosis: a multidatabase study. Mult Scler Relat Disord 41. https://doi.org/10. 1016/j.msard.2020.101982

126. Luna G, Alping P, Burman J, Fink K, Fogdell-Hahn A, Gunnarsson M, Hillert J, Langer-Gould A et al (2020) Infection risks among patients with multiple sclerosis treated with fingolimod, natalizumab, rituximab, and injectable therapies. JAMA Neurol 77:184-191. https://doi.org/10.1001/jamaneurol. 2019.3365

127. Wijnands JMA, Zhu F, Kingwell E, Fisk JD, Evans C, Marrie RA, Zhao Y, Tremlett H (2018) Disease-modifying drugs for multiple sclerosis and infection risk: a cohort study. J Neurol Neurosurg Psychiatry 89:1050-1056. https://doi.org/10.1136/jnnp-2017317493

128. Louapre C, Collongues N, Stankoff B, Giannesini C, Papeix C, Bensa C, Deschamps R, Créange A et al (2020) Clinical characteristics and outcomes in patients with Coronavirus Disease 2019 and multiple sclerosis. JAMA Neurol 77:1079-1088. https://doi. org/10.1001/jamaneurol.2020.2581

Publisher's Note Springer Nature remains neutral with regard to jurisdictional claims in published maps and institutional affiliations. 